\title{
Perancangan fungsi kendali mutu pada pengelolaan kolam pengendap perusahaan tambang batubara PT XYZ
}

\author{
R. Husin ${ }^{1 *}$, H. Wijayanto 2 , S. Hariyadi ${ }^{3}$ \\ ${ }^{1}$ Program Studi Pengelolaan Sumberdaya Alam dan Lingkungan, Institut Pertanian Bogor, Bogor, Indonesia \\ 2Departemen Statistika, Institut Pertanian Bogor, Bogor, Indonesia \\ ${ }^{3}$ Departemen Manajemen Sumberdaya Perairan, Institut Pertanian Bogor, Bogor, Indonesia
}

\begin{abstract}
Abstrak.
Pada tulisan ini, obyek penelitian dilakukan pada kegiatan penambangan di PT XYZ. PT XYZ menerapkan pengelolaan air tambang dengan menggunakan beberapa fasilitas kolam pengendapan yang selanjutnya disebut dengan settling-pond. Di PT XYZ, terdapat 14 kolam pengendap yang berfungsi untuk mengatasi $\mathrm{pH}$, TSS, Fe dan Mn. Penelitian ini dilakukan guna menemukan kendali mutu yang tepat dalam mengidentifikasi potensi deviasi dari baku mutu lingkungan hidup yang sudah ditetapkan dalam peraturan perundang-undangan. Kendali mutu guna menentukan control chart serta control limitnya dicari untuk masing-masing parameter $\mathrm{pH}, \mathrm{Fe}$ dan $\mathrm{Mn}$. Beberapa model alternatif sampling plan telah disusun untuk diujicobakan dengan beberapa control chart. Pilihan control chart yang dilibatkan dalam penelitian ini untuk dipilih adalah $\bar{X}-R$ Chart, $\bar{X}-s$ Chart dan XmR Chart. Pada penelitian ini, data setiap parameter dikumpulkan dan dilakukan uji stabilitas dan uji kapabilitas guna diputuskan control chart dan control limit-nya setiap parameter. Hasil penelitian menunjukkan untuk parameter $\mathrm{pH}, \mathrm{Fe}$ dan $\mathrm{Mn}$ control chart yang dapat digunakan adalah $\bar{X}-s$. Penerapan control chart di dalam pengelolaan air tambang PT XYZ terbukti dapat mengelola kinerja kepatuhannya terhadap peraturan perundang-undangan dengan mengedepankan pendekatan pencegahan dan perbaikan berkelanjutan.
\end{abstract}

Kata kunci: air tambang, control chart, pencegahan, perbaikan berkelanjutan

\begin{abstract}
.
The research was carried out in PT XYZ coal mining company. The company applies mine water management using some treatment ponds, so-called settling pond. The company have 14 settling ponds to treat $\mathrm{pH}$, TSS, Fe and Mn. This research was conducted to find the most suitable quality control in order to identify possible deviation against the defined criteria of the relevant regulation. There were three parameters of which the control chart and its control limit in this research to be determined, they were $\mathrm{pH}, \mathrm{Fe}$ and $\mathrm{Mn}$. Some alternative sampling plan models and three type of control charts were defined. The control charts to be involved in this research were $\bar{X}-R$ Chart, $\bar{X}-s$ Chart, and XmR. According to the defined sampling plan model and control charts, on each parameters, stability and capability testing were carried out to determine the most suitable control charts and their control limits. The research result has shown that for $\mathrm{pH}, \mathrm{Fe}$ and $\mathrm{Mn}$, the chosen control chart was $\bar{X}-\mathrm{s}$. The implementation of control chart in coal mining company of PT XYZ was proven able to manage its performance in meeting the stipulated regulation which emphasizes in prevention and continual improvement approach.
\end{abstract}

Keywords: mine water, control chart, prevention, continual improvement

\section{PENDAHULUAN}

Di Indonesia, perkembangan produksi batubara dari tahun 2010 sampai dengan tahun 2014 menunjukkan peningkatan yang cukup pesat, dengan kenaikan produksi rata-rata $15,68 \%$ per tahun. Pada tahun 2013, produksi batubara mencapai 474 juta ton dan pada tahun 2014 menunjukkan penurunan sebesar 3,43\% seperti yang terlihat pada Gambar 1. Penurunan ini disebabkan adanya pengurangan impor dari China serta Amerika dan beberapa negara Eropa akibat adanya upaya-upaya untuk mengurangi konsumsi batubara dan

\footnotetext{
${ }^{*}$ Korespondensi Penulis

Email : rusdi.husin@yahoo.co.id
} 
juga adanya temuan sumber daya alam minyak dan gas yang terjebak dalam batuan atau yang sering disebut dengan shale gas/shale oil (PerMenESDM Nomor 13 Tahun 2015 tentang Rencana Strategis Kementerian Energi dan Sumber Daya Mineral Tahun 2015-2019). Penurunan ini tentunya selaras dengan kebijakan bauran energi nasional untuk lebih mengoptimalkan penggunaan energi baru dan terbarukan serta utilisasi penggunaan gas bumi.

Sepanjang siklus pemanfaatan batubara mulai dari penambangan, pembakaran di boiler pembangkit listrik sampai pembuangan limbahnya, jika tidak dikelola dengan bijak dapat menimbulkan kerusakan yang sulit dielakkan. Pola eksploitasi batubara pada kebanyakan kasus masih mengedepankan penggunaan mazhab antroposentris, yakni pemanfaatannya lebih berorientasi kepada kepentingan ekonomi. Hingga saat ini masih banyak kalangan yang menganggap bahwa batubara merupakan aset untuk mengeruk keuntungan sebesar-besarnya sebagai sumber devisa tanpa memedulikan kelestariannya. Sebagai akibatnya, hal ini sangat mengancam keberlanjutan kehidupan manusia dan pembangunan (Alikodra 2012). Berkaitan dengan hal tersebut, data Kementerian ESDM (2015) menunjukkan bahwa produksi batubara nasional cenderung meningkat, sehingga berpotensi meningkatkan gangguan terhadap kualitas lingkungan hidup, tentunya jika tidak dikelola dengan baik.

Proses penambangan pada umumnya berhadapan dengan risiko ketergangguan air, baik dari sisi kualitas maupun kuantitas, baik terhadap air permukaan maupun air tanah. Proses pengambilan batuan penutup dan juga sumber daya mineral atau batubara akan memotong akuifer air tanah sehingga mengakibatkan air tersebut tercampur dengan tanah. Air limbah dari proses pertambangan batubara menghadapi permasalahan dengan isu keasaman air dan logam berat. Batuan penutup yang mengandung mineral sulfida $\left(\mathrm{FeS}_{2}\right)$, sebelum proses penambangan berada dalam tanah dan tertutup, maka ketika penambangan terjadi, akan terbuka dan terdedah dengan udara, sehingga mengakibatkan terjadinya oksidasi. Begitu bebatuan yang sudah terdedah oksigen terkena air, maka terjadilah Air Asam Tambang (AAT) (Gautama 2014). Nilai $\mathrm{pH}$ yang sangat rendah akan melarutkan logam-logam berat dan tentunya jika tidak diolah akan mengakibatkan gangguan terhadap manusia dan biota air.

Obyek penelitian ini adalah perusahaan tambang yang berada di Kalimantan Selatan dan menurut data BPS (2017), pada periode 2015 dan 2016 sungai-sungai di Kalimantan Selatan, yaitu Barito, Martapuran, Riam Kiwa dan Nagara dalam status cemar berat. Obyek penelitian dilakukan pada kegiatan penambangan di PT XYZ. PT XYZ menerapkan pengelolaan air tambang dengan menggunakan beberapa fasilitas kolam pengendapan yang selanjutnya disebut dengan settling-pond. Kolam pengendap tersebut digunakan untuk mengolah air agar kualitas airnya memenuhi baku mutu lingkungan hidup seperti yang 
tertuang dalam KepMenLH Nomor 113 Tahun 2003 tentang Baku Mutu Air Limbah Bagi Usaha dan/atau Kegiatan Pertambangan Batubara. Berhubung PT XYZ berlokasi di provinsi Kalimantan Selatan, maka terdapat peraturan daerah yang diterbitkan oleh Gubernur yaitu PerGub Kalimantan Selatan Nomor 036 Tahun 2008, dengan aturan yang lebih ketat terhadap parameter TSS dibandingkan dengan yang tercantum pada KepMenLH Nomor 113 Tahun 2003. Tiga parameter yang wajib dipenuhi oleh PT XYZ adalah $\mathrm{pH}$ dengan kisaran 6-9, Fe (sebagai total) sebesar $7 \mathrm{mg} / \mathrm{l}$ dan $\mathrm{Mn}$ (sebagai total) sebesar $4 \mathrm{mg} / \mathrm{l}$. Struktur settling-pond (SP) pada tambang batubara PT XYZ disajikan pada Gambar 1.

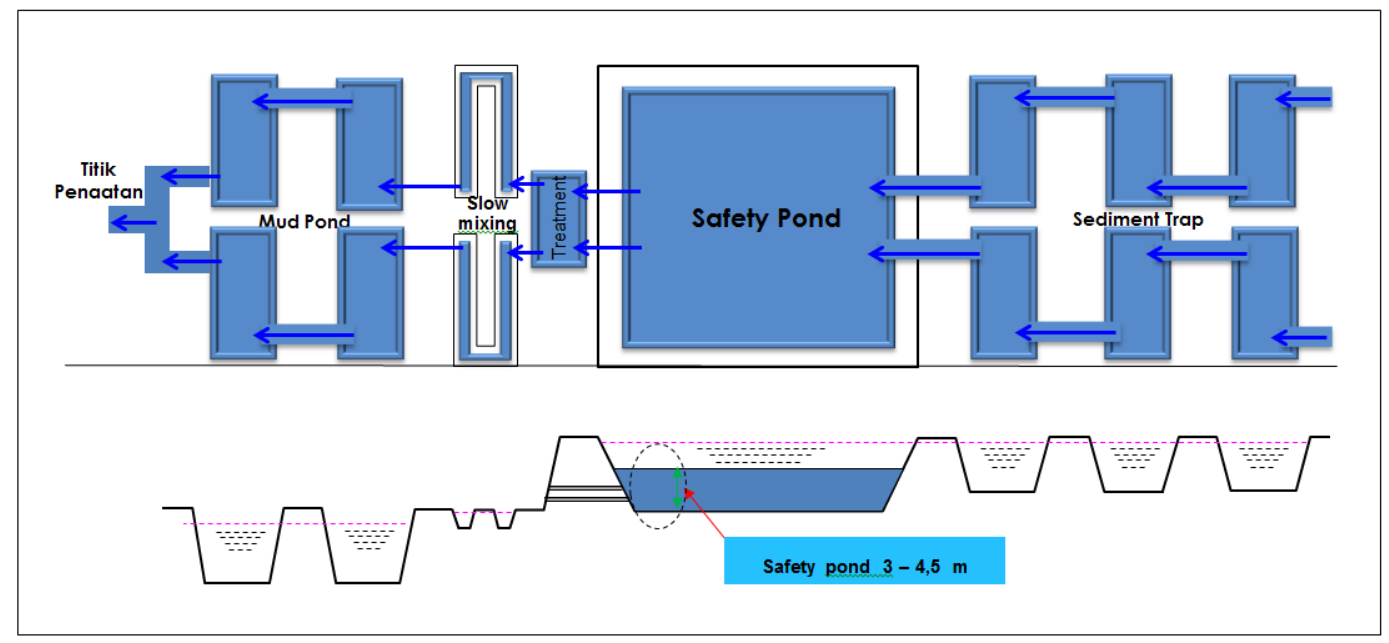

Gambar 1. Pola pengelolaan air tambang.

Di dalam standar ISO 9000:2015, kendali mutu atau quality control didefinisikan sebagai bagian dari manajemen mutu yang difokuskan untuk memenuhi persyaratan mutu, sedangkan dalam standar tersebut, manajemen mutu didefinisikan sebagai pengelolaan yang terkait dengan mutu. Penerapan kendali mutu dalam rencana penelitian ini dikembangkan dengan mengadopsi konsep statistical process control (SPC). SAI Global Indonesia (2011) mendefinisikan SPC sebagai suatu metode pemecahan masalah untuk mengumpulkan dan menganalisa data sedemikian rupa sehingga dapat memahami permasalahan dan bertindak untuk menstabilkan proses, mengurangi variasi dan memperbaiki kapabilitas. Penerapan statistical process control juga melibatkan tata kelola terkait dengan pengukuran, kemudian menerapkan pemantauan dengan menggunakan control chart, serta mengevaluasi kinerja dengan menggunakan indeks kapabilitas proses (Corbet and Pan 2001). Konsep tersebut dapat diilustrasikan dalam Gambar 2. 


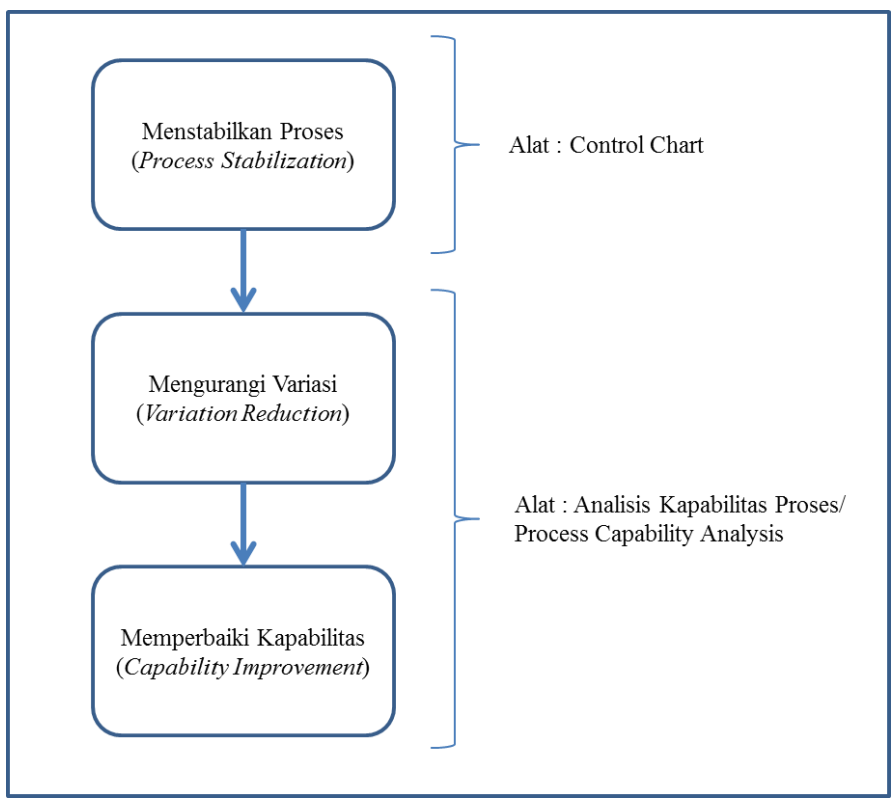

Gambar 2. Pola implementasi statistical process control.

Pzydek (2003) menyatakan penyebab variasi acak yang tidak diketahui disebut sebagai common cause, dalam beberapa referensi lain disebut sebagai $a$ chance cause. Jika pengaruh dari variasi relatif kecil, maka dapat dikatakan bahwa variasi yang ada dapat diprediksi dalam batas kendali. Perlu untuk dikatakan bahwa tidak semua fenomena muncul dari sistem yang konstan dari suatu variasi common cause. Ada saat-saat tertentu, variasi disebabkan oleh sumber variasi yang bukan dari suatu proses yang konstan. Penyebab variasi ini disebut sebagai special causes atau dalam beberapa referensi disebut sebagai assignable causes. Dhini and Surjandari (2016) menyatakan bahwa penerapan control chart juga bertujuan untuk mendeteksi adanya variasi, baik yang disebabkan oleh common cause maupun special cause.

Penggunaan control chart yang efektif salah satunya tergantung kepada rational subgroup termasuk juga pengambilan sampel yang rasional (rational sampling). Upaya perlu difokuskan kepada teknik sederhana yang dapat menghasilkan hasil analisis yang terbaik. Rational sampling melibatkan pemilihan terbaik terhadap apa, dimana, bagaimana dan kapan pengukuran dilakukan. Frekuensi pengambilan sampel dikatakan rasional jika pengambilannya cukup sering untuk mendeteksi atau memantau perubahanperubahan proses. Penulis menyebut perancangan rational subgroup dan rational sampling dengan istilah perancangan sampling plan.

Tulisan ini ditujukan untuk mendapatkan bentuk control chart kendali mutu pengelolaan air tambang yang sesuai untuk masing-masing parameter baik 
$\mathrm{pH}, \mathrm{Fe}$ dan Mn. Selain itu, ingin mengetahui pula control limit yang diperlukan guna memantau kualitas air tambang untuk parameter $\mathrm{pH}$, Fe dan Mn. Hal yang tidak kalah penting, adalah mengetahui sistem kendali mutu yang cocok bagi pengelolaan air tambang agar dapat sedini mungkin mencegah pencemaran ke badan air sungai (early-warning-system).

\section{METODOLOGI}

\subsection{Lokasi kajian dan waktu penelitian}

Penelitian ini dilakukan di tambang PT XYZ di Provinsi Kalimantan Selatan. Pengumpulan data dilakukan melalui pengambilan data dari aplikasi perangkat lunak yang telah digunakan oleh PT XYZ. Data yang diambil adalah data $\mathrm{pH}, \mathrm{Fe}$ dan Mn selama kurun waktu tahun 2017 dan periode Januari-April 2018. Implementasi dari setiap model alternatif dan control chart yang terpilih dilaksanakan pada periode Mei-Desember 2018. Jumlah kolam pengendap yang dianalisis sejumlah 14 buah dengan identitas kolam pengendap A sampai $\mathrm{N}$.

\subsection{Tahapan penelitian}

Tahapan penelitian diilustrasikan sesuai dengan Gambar 3.

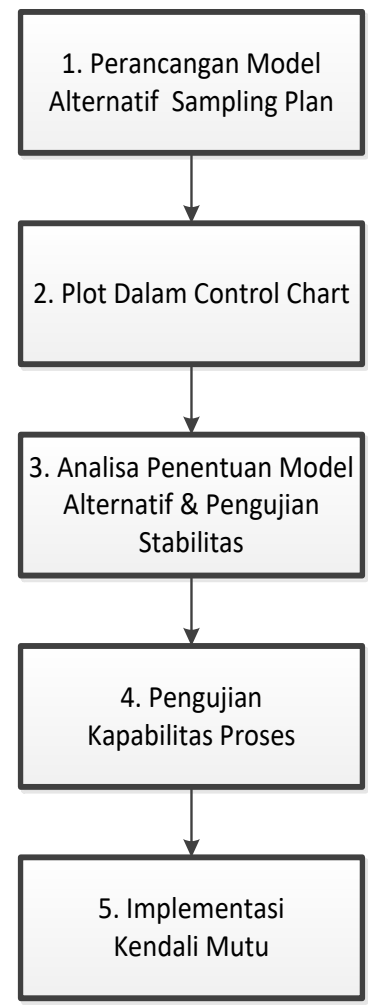

Gambar 3. Tahapan perancangan kendali mutu. 


\subsubsection{Perancangan model alternatif sampling plan}

\subsubsection{Model alternatif I}

Sampling plan alternatif pertama ini disusun untuk setiap kolam pengendap. Dengan demikian pendekatan yang dilakukan adalah mengambil data untuk masing-masing parameter setiap bulan untuk masing-masing kolam pengendap, sehingga subgroup size-nya adalah 1 . Berdasarkan model alternatif pertama ini, control chart yang cocok adalah X-MR.

\subsubsection{Model alternatif II}

Model alternatif kedua ini mengusulkan semua kolam pengendap SP-TSS diletakkan menjadi satu kelompok untuk dikembangkan 1 model sampling plan. Berbeda dengan model alternatif I yang masing-masing kolam pengendap dibuatkan sampling plan-nya. Pada model alternatif II ini data setiap kolam pengendap untuk kurun waktu Januari 2017-April 2018 diletakkan pada satu subgrup. Dengan demikian model alternatif II ini mengusulkan variasi data antar kolam pengendap sebagai between subgroup variation, sedangkan variasi within subgroup variation menunjukkan variasi data antar bulan. Didapatkan pada model alternatif II ini ukuran subgrup sebesar 16.

\subsubsection{Model alternatif III}

Model alternatif III ini, hampir mirip dengan model alternatif II, yakni mengusulkan variasi data antar bulan sebagai between subgroup variation, sedangkan variasi within subgroup variation menunjukkan variasi data parameter antar kolam pengendap. Didapatkan pada model alternatif II ini ukuran subgrup sebesar 14 .

\subsubsection{Uji kapabilitas proses (indeks Cp dan Cpk)}

Kapabilitas proses adalah ukuran statistik dari variasi inheren pada suatu peristiwa tertentu dalam suatu proses. Biasanya didefinisikan sebagai lebarnya proses yang dibagi oleh enam sigma dan diukur dengan menggunakan indeks kapabilitas (capability index, $\mathrm{Cp}$ ), dengan kata lain $\mathrm{Cp}$ diartikan sebagai kemampuan proses tersebut untuk mencapai hasil tertentu. Menurut Breyfogle (1999), Cp menjabarkan sebaran toleransi yang diperbolehkan terhadap sebaran data aktual ketika data mengikuti distribusi normal. Spesifikasi proses atau produk memiliki batas atas (USL, Upper Specification Limit) dan batas bawah (LSL, Lower Specification Limit). Jika proses memiliki kapabilitas yang baik, proses itu akan menghasilkan produk yang berada dalam batas-batas spesifikasi. Sebaliknya, apabila proses memiliki kapabilitas yang tidak baik, proses itu akan menghasilkan banyak produk yang berada di luar batas-batas spesifikasi atau mempunyai potensi besar untuk keluar dari batas toleransi/spesifikasi, sehingga menimbulkan kerugian karena banyak produk yang ditolak. Apabila ditemukan banyak produk yang ditolak, hal itu 
mengindikasikan bahwa proses produksi memiliki kemampuan proses yang rendah untuk menghasilkan output sesuai dengan yang diharapkan. Indeks kapabilitas proses (Cp) dihitung menggunakan rumus berikut:

$$
\mathrm{C}_{\mathrm{p}}=\frac{\mathrm{USL}-\mathrm{LSL}}{6 \sigma}
$$

Gambar 4 menunjukkan berbagai nilai $\mathrm{Cp}$ relatif terhadap nilai spesifikasinya. $\mathrm{Cp}$ menunjukkan bentuk sebaran dari suatu proses atau produk.

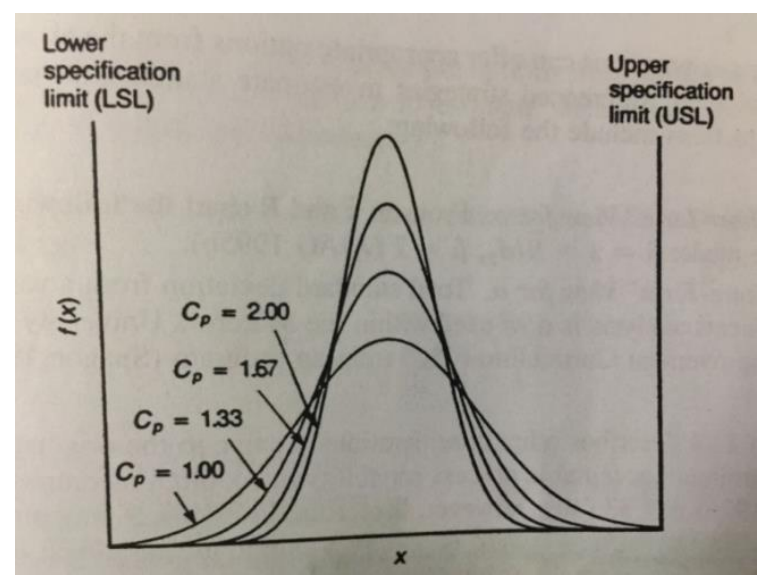

Gambar 4. Contoh-contoh Cp, direproduksi dari Breyfogle (1999).

Indeks Cpk digunakan sebagai ukuran untuk melihat sebaran dan juga pergeseran rata-rata data proses atau produk. Nilai Cpk diambil dari nilai terkecil dari kemampuan memenuhi spesifikasi atas dan spesifikasi bawah. Jika yang tersedia hanya salah satu dari spesifikasi, maka yang digunakan adalah kemampuan proses dalam memenuhi spesifikasi yang ada.

$$
\mathrm{C}_{\mathrm{pk}}=\min \left[\frac{\mathrm{USL}-\mu}{3 \sigma}, \frac{\mu-\mathrm{LSL}}{3 \sigma}\right]
$$

Pzydek (2003) mengusulkan nilai indeks Cp dan Cpk adalah minimal 1,00 dan akan lebih baik jika diatas 1,33.

\subsubsection{Uji stabilitas (control chart)}

Secara sederhana isu rational subgrouping melibatkan pemilihan dari sampel yang menghasilkan kondisi yang relatif homogen dalam suatu subgrup untuk suatu area atau region waktu (misalkan lima data dalam suatu baris). Dengan demikian variasi dalam suatu subgrup (within-subgroup variation) menentukan batas-batas control chart terhadap seberapa banyak variasi yang ada antar subgrup. Untuk kondisi tertentu mekanisme pen-subgrup-an yang berbeda akan secara dramatis mempengaruhi variasi within-subgroup yang pada akhirnya akan memberikan pengaruh terhadap lebar batas dari suatu control 
chart. Pen-subgrup-an dapat mempengaruhi keluaran dan menghasilkan keputusan terhadap kinerja suatu proses dengan menggunakan suatu control chart, misalnya $\bar{x}$ dan $\mathrm{R}$ chart. Chart rata-rata ( $\bar{x}$ chart) menunjukkan variasi antar subgrup (between-subgroup variation), sedangkan range chart ( $\mathrm{R}$ chart) menunjukkan variasi di dalam subgrup (within-subgroup variation). Variasi within-subgroup menentukan sensitivitas dari suatu control chart, untuk itu penting mempertimbangkan sumber-sumber variasi untuk suatu pengukuran dan selanjutnya mengatur penentuan subgrup (Breyfogle 1999). Pzydek (2003) menyatakan konsep subgrup akan sedikit membingungkan pada single control chart (individual x chart) dan menyatakan konsep subgrup hanya cocok untuk unit pengukuran yang lebih dari satu.

Terdapat dua kelompok besar control chart yang ada, yaitu control chart yang digunakan untuk data variabel (continuous data) dan control chart untuk data attribute (count data). Sehubungan data yang digunakan pada penelitian ini adalah data variabel, pembahasan control chart difokuskan pada control chart untuk data variabel. Tiga control chart untuk data variabel yang akan digunakan pada penelitian ini adalah:

a. Averages and Range $(\bar{x}-R$ Chart) (digunakan jika $1<$ ukuran subgroup $<10$ ).

b. Averages and Standard Deviation $(\bar{x}-s$ Chart) (digunakan jika ukuran subgroup $>10$ ).

c. Individual Measurements (XmR Chart) (digunakan jika ukuran subgroup sebesar 1).

Masing-masing formula dari ketiga control chart disajikan pada Gambar 5.

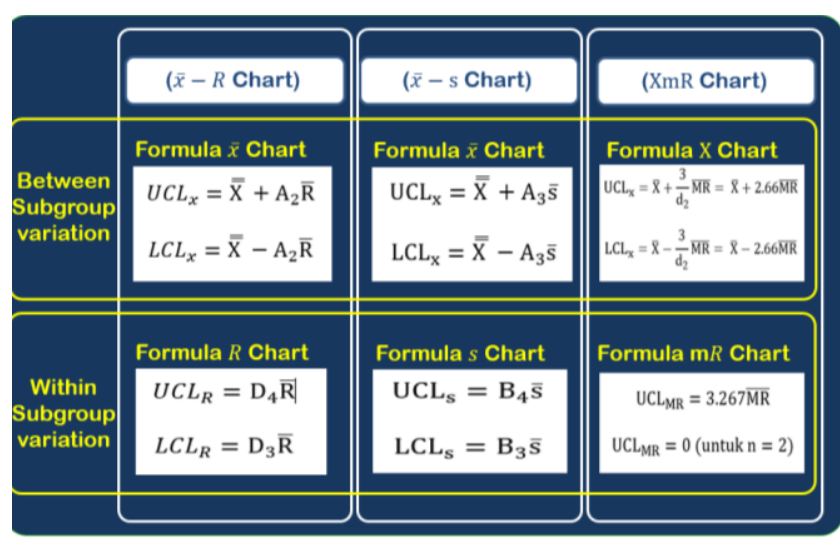

Gambar 5. Formula control chart.

Analisis lebih lanjut dari data yang sudah diplot ke dalam suatu control chart adalah untuk melihat apakah suatu proses dapat disebut stabil/tidak. Jika ketidakstabilan ditemukan, maka batas kendali yang ada (CL, UCL dan LCL) tidak 
dapat digunakan untuk mengendalikan proses dari waktu ke waktu. Ketidakstabilan yang ditemui perlu dilakukan perbaikan dan selanjutnya perlu diplot ke dalam control chart guna dilihat kestabilannya. Jika sudah stabil, dengan cara menghilangkan penyebab yang ada, maka batas kendali yang ada dapat digunakan untuk mengendalikan proses dari waktu ke waktu, setelah melalui proses pengujian kapabilitasnya terlebih dahulu.

Tasdemir and Kowalczuk (2013) menyatakan bahwa penggunaan control chart efektif dalam mendeteksi pergeseran kinerja proses, karena kalau tidak dideteksi dengan segera, dimungkinkan akan dapat terjadi penyimpanganpenyimpangan yang tidak diharapkan. Shewhart in Breyfogle (1999) menyatakan bahwa batas kendali berada pada $+/-3 \sigma$, maka control chart dapat digambarkan seperti pada Gambar 6.

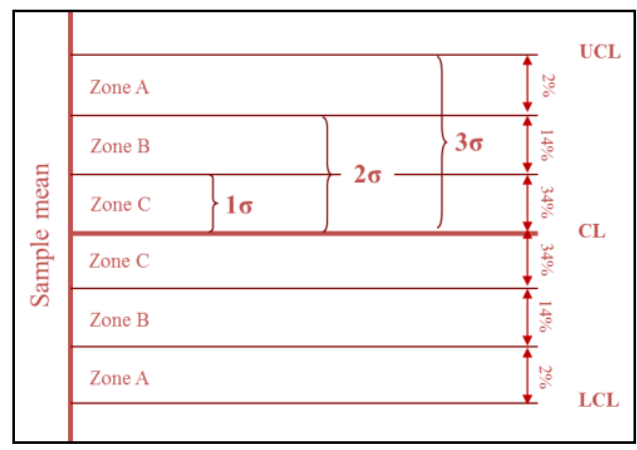

Gambar 6. Zone control chart Shewhart, direproduksi dari Breyfogle (1999).

SAI Global Indonesia (2011) menyatakan bahwa terdapat 6 kondisi yang menunjukkan terjadinya ketidakstabilan, yakni:

1. Satu titik keluar dari zone A.

2. Dua dari tiga titik berada di zone A.

3. Empat dari lima titik berada di zone A.

4. Delapan titik berada di zone $\mathrm{C}$.

5. Enam titik berturut-turut naik atau turun.

6. Enam titik berturut-turut berada di bawah atau di atas center line.

\section{HASIL DAN PEMBAHASAN}

\subsection{Analisis penentuan model alternatif parameter $\mathbf{p H}$}

Pada model alternatif I, dengan control chart XmR, terlihat 6 dari 14 kolam pengendap dapat memenuhi indeks kapabilitas, yaitu kolam A, C, G, H, L dan N. Pada uji stabilitas, hanya kolam $C$ yang menunjukkan ketidakstabilan.

Pada model alternatif II, dengan control chart $\bar{X}-s$, diperoleh indeks $\mathrm{Cpk}$ sebesar 1,04, artinya dapat memenuhi standar indeks Cpk (minimal 1). Pada uji stabilitas, tidak terlihat adanya kondisi ketidakstabilan. Pada model alternatif III 
dengan control chart $\bar{X}-s$, indeks Cpk-nya sebesar 0,296 yang tentunya tidak dapat memenuhi standar indeks Cpk. Disamping itu, terdapat dua kondisi ketidakstabilan yakni kondisi nomor 1 dan 2.

Dengan demikian dapat disimpulkan model alternatif untuk parameter $\mathrm{pH}$ kolam pengendap TSS yang paling tepat adalah model alternatif II dengan control chart yang digunakan adalah $\bar{X}-s$. Pada model alternatif II ini batas kendali yang dapat digunakan adalah:

- Untuk control chart $\bar{X}$

- $\mathrm{UCLx}=7,82$

- $\operatorname{CLx}=7,47$

- $\operatorname{LCLx}=7,11$

- Untuk control chart s

- UCLs $=0,72$

- CLs $=0,46$

- LCLs =0,21

Berdasarkan control limit yang telah ditetapkan di atas, maka di lapangan dilaksanakan tahapan penerapannya. Semua SP-TSS untuk parameter $\mathrm{pH}$ setiap bulannya diplot ke dalam control chart untuk melihat apakah ada kondisi ketidakstabilan. Perbaikan dilakukan guna mengatasi ketidakstabilan yang ada. Berikut hasil pelaksanaan kendali proses untuk parameter $\mathrm{pH}$ selama kurun waktu Mei-Desember 2018.

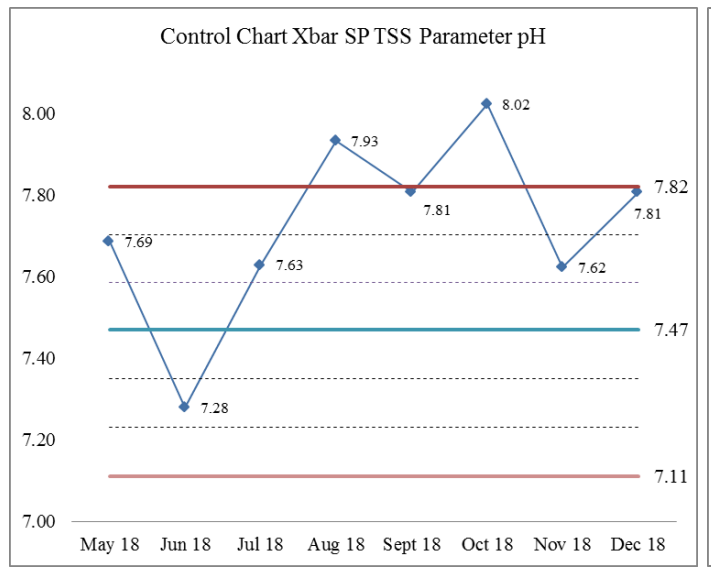

Gambar 7. Implementasi kendali mutu parameter $\mathrm{pH}$ kolam pengendap TSS control chart $\overline{\mathbf{X}}$.

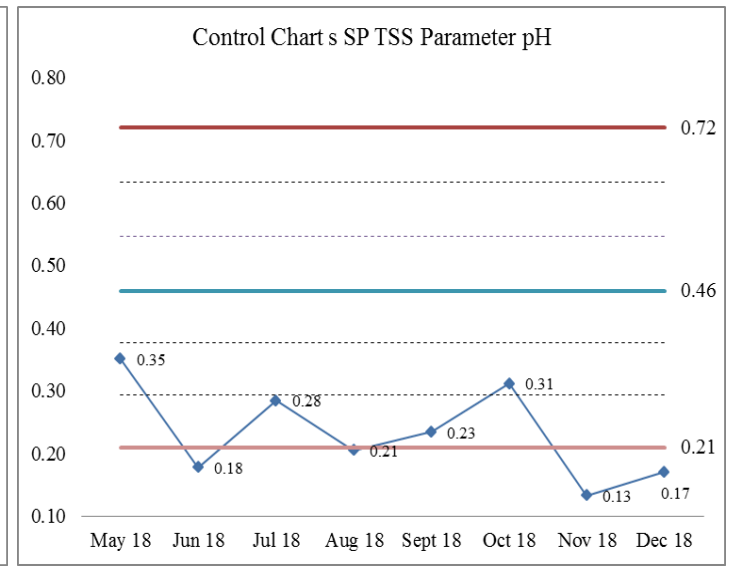

Gambar 8. Implementasi kendali mutu parameter $\mathrm{pH}$ kolam pengendap TSS dengan control chart s.

Berdasarkan Gambar 7, dapat terlihat kondisi ketidakstabilan nomor 1. Titik ketidakstabilan terjadi pada bulan Agustus dan Oktober. Hasil penerapan kendali kualitas dengan menggunakan control chart s dapat dilihat pada Gambar 
8. Pada kendali proses dengan control chart $\mathrm{s}$ terlihat semua parameter $\mathrm{pH}$ berada pada sisi bawah center line. Pada beberapa bulan, yaitu bulan Juni, November dan Desember berada di bawah LCL. Namun kondisi ini bukan sesuatu yang perlu dikhawatirkan, mengingat semakin kecil variasi semakin baik kualitas suatu proses.

\subsection{Analisis penentuan model alternatif parameter Fe}

Pada model alternatif I, dengan control chart XmR, terlihat bahwa semua kolam pengendap TSS berdasarkan indeks Cpk memenuhi standar (minimal 1). Namun pada uji stabilitas, beberapa kolam pengendap menunjukkan kondisi ketidakstabilan, yaitu kolam pengendap B, C, D, F, H, I dan K. Dengan demikian 7 dari 14 kolam pengendap atau 50\% menunjukkan ketidakstabilan.

Pada model alternatif II, dengan control chart $\bar{X}-s$, diperoleh indeks Cpk sebesar 4,17 yang dapat memenuhi standar indeks Cpk. Namun, pada uji stabilitas terlihat adanya dua kondisi ketidakstabilan yaitu kondisi nomor 1 (keluar dari batas kendali) dan nomor 2 (dua dari tiga titik berada di zone $3 \mathrm{~A}$ ).

Pada model alternatif III dengan control chart $\bar{X}-s$, diperoleh indeks Cpk sebesar 3,28 yang dapat memenuhi indeks standar Cpk. Pada uji stabilitas terlihat adanya kondisi ketidakstabilan yang keluar dari batas kendali bawah, namun hal ini bukanlah masalah karena beban pencemarnya justru paling kecil.

Dengan demikian dapat disimpulkan model alternatif untuk parameter Fe kolam pengendap TSS yang paling tepat adalah model alternatif III dengan control chart yang digunakan adalah $\bar{X}-s$. Pada model alternatif III ini batas kendali yang dapat digunakan adalah:

- Untuk control chart $\bar{X}$

- $\mathrm{UCLx}=1,13 \mathrm{mg} / \mathrm{L}$

- $\mathrm{CLx}=0,61 \mathrm{mg} / \mathrm{L}$

- $\mathrm{LCLx}=0,09 \mathrm{mg} / \mathrm{L}$

- Untuk control chart s

- UCLs $=1,02$

- $\mathrm{CLs}=0,64$

- LCLs =0,26

Berdasarkan control limit yang telah ditetapkan di atas, maka di lapangan dilaksanakan tahapan penerapannya. Semua SP-TSS untuk parameter Fe setiap bulannya diplot ke dalam control chart untuk melihat apakah ada kondisi ketidakstabilan. Tentunya di lapangan, perbaikan dilakukan guna mengatasi ketidakstabilan yang ada. Berikut hasil pelaksanaan kendali proses untuk parameter Fe selama kurun waktu Mei-Desember 2018. 


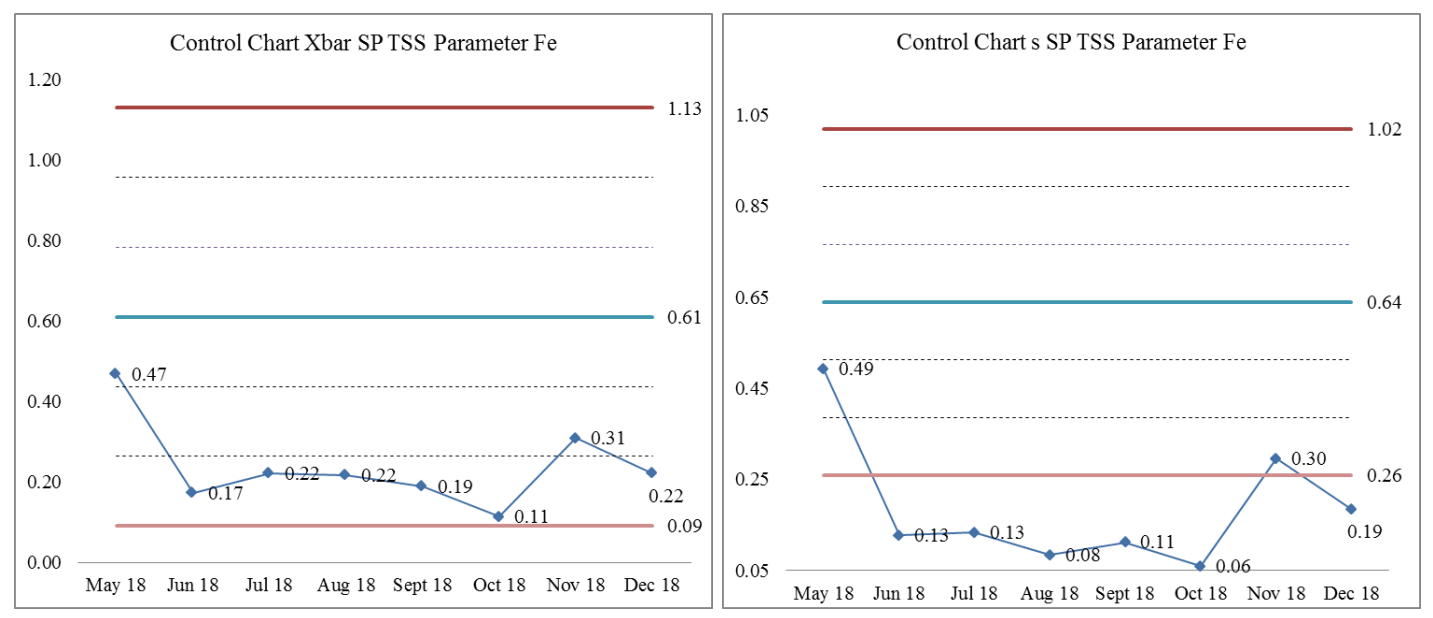

Gambar 9. Implementasi kendali mutu parameter Fe kolam pengendap TSS control $\operatorname{chart} \overline{\mathbf{X}}$.
Gambar 10. Implementasi kendali mutu parameter Fe kolam pengendap TSS dengan control chart s.

Berdasarkan Gambar 9 dan 10, dapat terlihat bahwa seluruh data berada di bawah center line. Pada kendali proses dengan control chart s terlihat semua parameter Fe berada pada sisi bawah center line, hanya pada dua bulan saja berada di dalam batas kendali yaitu Mei dan November.

\subsection{Analisis penentuan model alternatif parameter Mn}

Pada model alternatif I, dengan control chart XmR, terlihat bahwa semua kolam pengendap TSS berdasarkan indeks Cpk memenuhi standar (minimal 1). Namun pada uji stabilitas, hanya 3 kolam pengendap atau 21\% dari keseluruhan kolam, yang menunjukkan kestabilan yaitu kolam C, D dan J.

Pada model alternatif II dengan control chart $\bar{X}-s$, diperoleh indeks Cpk sebesar 2,88 yang dapat memenuhi standar indeks Cpk. Namun pada uji stabilitas, terlihat kondisi ketidakstabilan nomor 1 (keluar dari batas kendali), baik pada control chart $\bar{X}$ maupun control chart s.

Pada model alternatif III dengan control chart $\bar{X}-s$, diperoleh indeks Cpk sebesar 8,85 yang mampu memenuhi indeks standar Cpk. Berdasarkan uji stabilitas, terdapat kondisi yang menunjukkan pola ketidakstabilan pada control chart $\bar{X}$ yakni kondisi ketidakstabilan nomor 1 dan 3 .

Untuk parameter $\mathrm{Mn}$ ini, penulis merasa kesulitan dalam mengambil keputusan paling tepat dari tiga model alternatif yang ada, namun dapat dilihat bahwa model II dirasa paling baik dibandingkan dengan model I dan III. Dengan demikian diusulkan model alternatif untuk parameter Mn kolam pengendap TSS adalah model alternatif II dengan control chart yang digunakan adalah $\bar{X}-s$. Pada model alternatif II ini batas kendali yang dapat digunakan adalah: 
- Untuk control chart $\bar{X}$

- $\mathrm{UCLx}=0,68 \mathrm{mg} / \mathrm{L}$

- $\mathrm{CLx}=0,37 \mathrm{mg} / \mathrm{L}$

- $\operatorname{LCLx}=0,05 \mathrm{mg} / \mathrm{L}$

- Untuk control chart s

- UCLs $=0,64$

- $\mathrm{CLs}=0,41$

- LCLs = 0,19

Berdasarkan control limit yang telah ditetapkan di atas, maka di lapangan dilaksanakan tahapan penerapannya. Semua SP TSS untuk parameter Mn setiap bulannya diplot ke dalam control chart untuk melihat apakah ada kondisi ketidakstabilan. Tentunya di lapangan, perbaikan dilakukan guna mengatasi ketidakstabilan yang ada. Berikut hasil pelaksanaan kendali proses untuk parameter Mn selama kurun waktu Mei-Desember 2018.

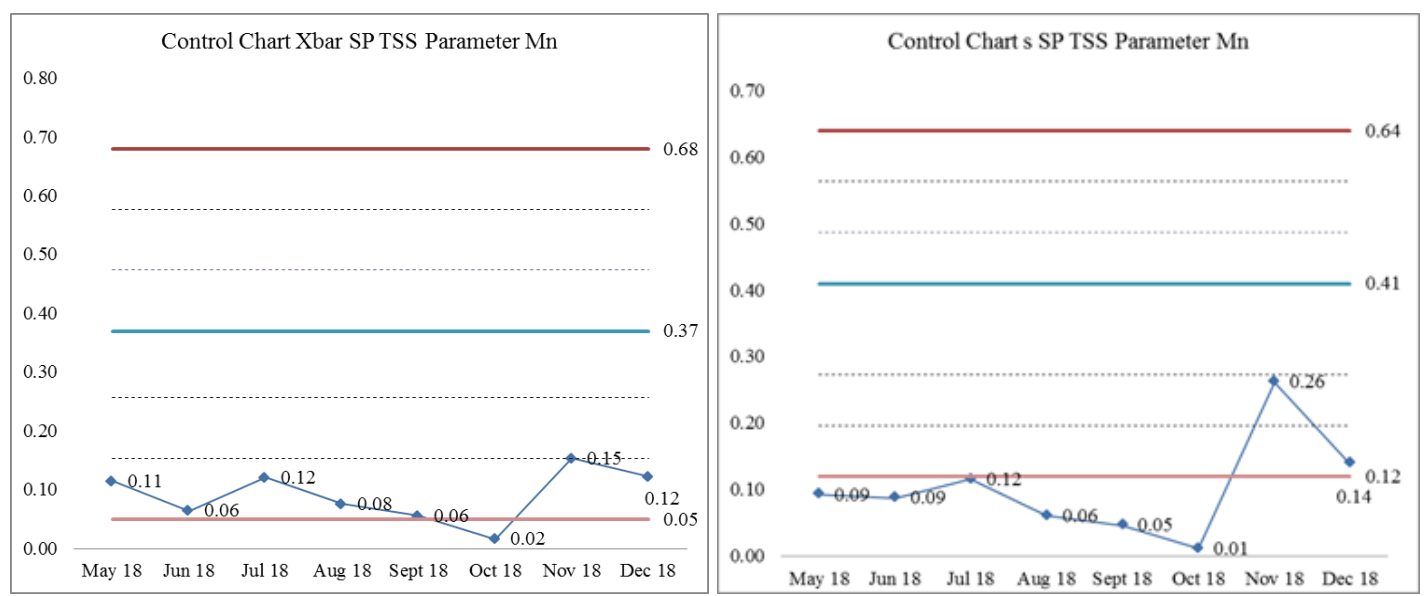

Gambar 11. Implementasi kendali mutu parameter Mn kolam pengendap TSS control chart $\overline{\mathbf{X}}$.

Gambar 12. Implementasi kendali mutu parameter Mn kolam pengendap TSS dengan control chart s.

Berdasarkan Gambar 11, dapat terlihat bahwa seluruh data berada di bawah center line, bahkan pada bulan Oktober berada di bawah LCL.Ppenerapan kendali kualitas dengan menggunakan control chart s, hasilnya dapat dilihat pada Gambar 12. Pada kendali proses dengan control chart s terlihat semua parameter Mn berada pada sisi bawah center line dan hanya dua bulan saja yang berada di dalam batas kendali, yaitu November dan Desember.

\section{KESIMPULAN DAN SARAN}

Berdasarkan hasil analisis, control chart yang tepat digunakan untuk parameter $\mathrm{pH}, \mathrm{Fe}$ dan $\mathrm{Mn}$ adalah $\bar{X}-s$. Penerapan control chart sesuai dengan 
tahapan kendali mutu lingkungan hidup yang sudah dikembangkan, baik pada kolam pengendap TSS maupun $\mathrm{pH}$ terlihat cukup efektif dalam mendeteksi adanya potensi-potensi penyimpangan dari baku mutu yang ada. Dengan demikian, penggunaan control chart pada pengelolaan air tambang sangat tepat dalam mencegah kejadian pelanggaran terhadap baku mutu lingkungan hidup yang ditetapkan oleh pemerintah. Disamping itu inisiatif ini terbukti dapat mendukung program perbaikan berkelanjutan atau Continual Improvement Program yang pada banyak perusahaan digalakan dengan sangat kuat.

\section{DAFTAR PUSTAKA}

Alikodra H. 2012. Konservasi sumber daya alam dan lingkungan. Gadjah Mada University Press. Yogyakarta.

[BPS] Badan Pusat Statistik. Statistik Lingkungan Hidup 2017. BPS. Jakarta.

Breyfogle FW. 1999. Implementing six sigma (smarter solutions using statistical method). John Wiley \& Sons, Inc. New York.

Corbet CJ and Pan J. 2001. Evaluating environmental performance using statistical process control techniques. European Journal of Operational Research 139(2002):68-63.

Dhini A and Surjandari I. 2016. Review on some multivariate statistical process control methods for process monitoring [Proceeding]. Proceeding of the 2016 International Conference on Industrial Engineering and Operations Management. IEOM Society. Kuala Lumpur.

Gautama RS. 2014. Pembentukan, pengendalian dan pengelolaan air asam tambang. ITB Press. Bandung.

[ISO] International Organization for Standardization 9000:2015. 2015. Quality management systems-fundamental and vocabulary, fourth edition. ISO. Geneva.

[Kementerian ESDM] Kementerian Energi dan Sumber Daya Mineral. 2015. Indonesia mineral and coal information. Direktorat Jenderal Mineral dan Batubara, Kementerian ESDM. Jakarta. p 66.

KepMenLH (Keputusan Menteri Lingkungan Hidup) Nomor 113 Tahun 2003 tentang baku mutu air limbah bagi usaha dan atau kegiatan pertambangan batubara.

PerGub (Peraturan Gubernur) Kalimantan Selatan Nomor 036 Tahun 2008 tentang perubahan atas PerGub Kalimantan Selatan Nomor 04 Tahun 2007 tentang baku mutu limbah cair (BMLC) bagi industri, hotel, restoran, rumah sakit, domestik dan pertambangan.

PerMenESDM (Peraturan Menteri Energi dan Sumber Daya Mineral) Nomor 13 Tahun 2015 tentang rencana strategis Kementerian Energi dan Sumber Daya Mineral tahun 2015-2019. 
Pzydek T. 2003. The six sigma handbook, revised and expanded (a complete guide for green belts, black belts, and managers at all levels). Mc-Graw Hill. New York.

SAI Global Indonesia. 2011. Statistical process control. Jakarta.

Tasdemir A and Kowalczuk PB. 2013. Application of statistical process control for proper processing of the ore sudetic monocline copper ore. Physicochemical Problems of Mineral Processing 50(1): 249-264. 